\title{
Figure S2
}
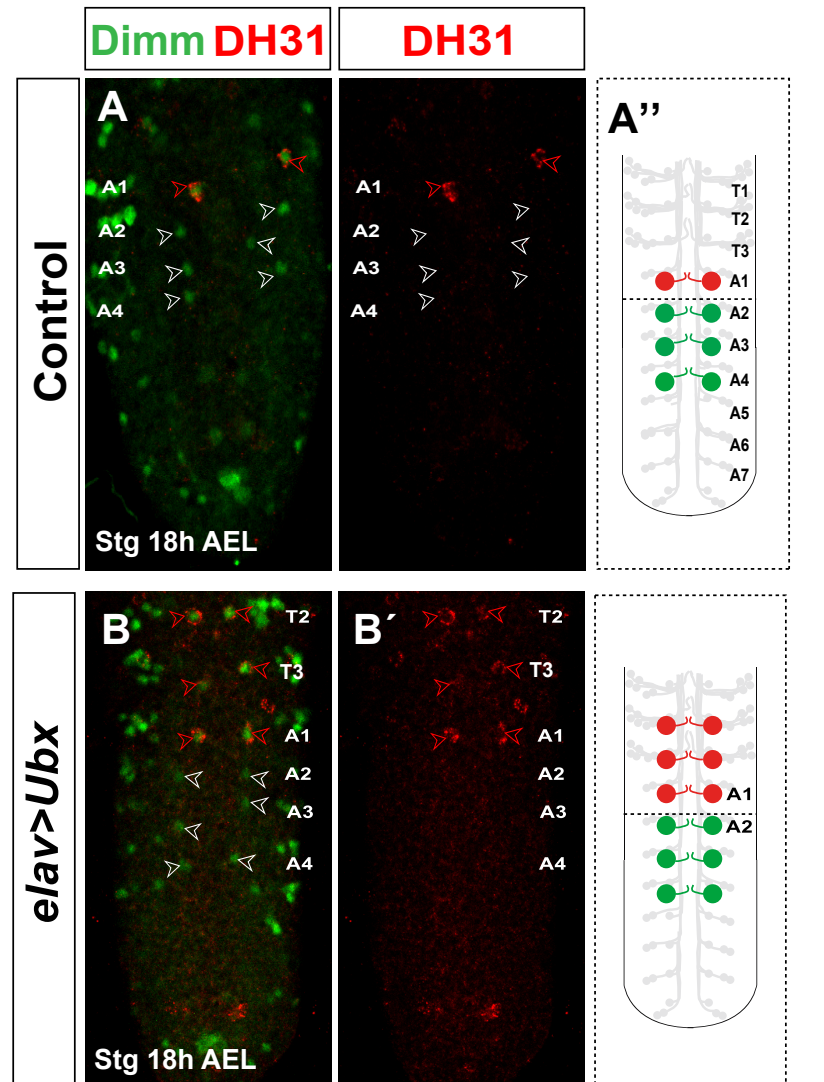

E
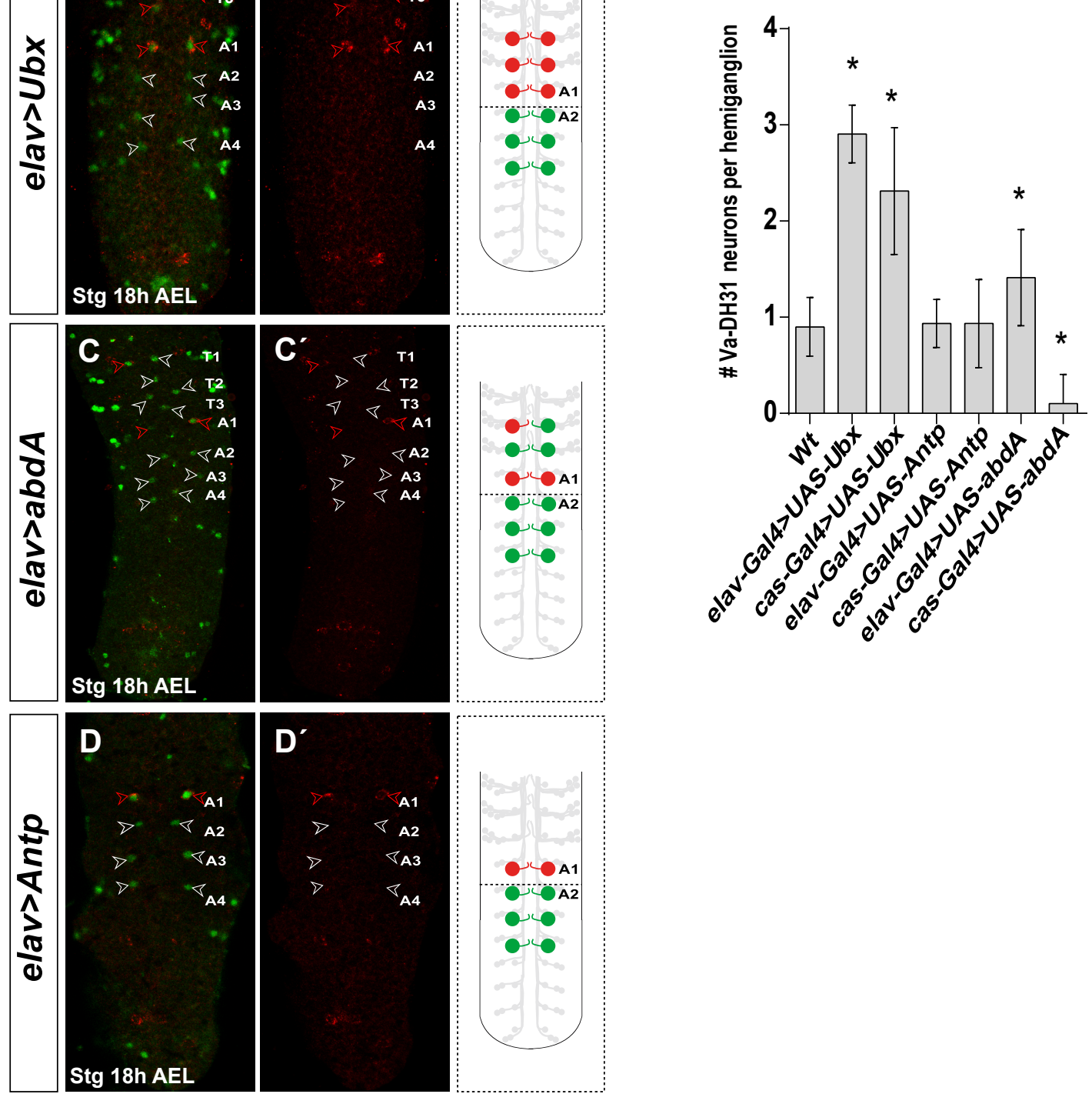